\title{
Low-Density Lipoprotein Receptor-Related Protein 1B
}

National Cancer Institute

\section{Source}

National Cancer Institute. Low-Density Lipoprotein Receptor-Related Protein 1B. NCI

Thesaurus. Code C111834.

Low-density lipoprotein receptor-related protein 1B (4599 aa, 515 kDa) is encoded by the human LRP1B gene. This protein plays a role in the metabolism of low density lipoproteins. 